\title{
Final Report for "Global Survey of Carbon Dioxide in the
}

\author{
Ocean" \\ Grant Number: DE-FG02-93ER61540 \\ J. L. Sarmiento, R. M. Key and C. L. Sabine \\ July, 1998
}

\section{Summary}

In the five years covered by this grant we have built a state-of-the-art, high precision, seagoing $\mathrm{CO}_{2}$ lab from scratch. We started off small, helping T. Takahashi's group make measurements as we built our instruments and trained personnel. Our first cruise with total responsibility for carbon measurements was near the end of the first year. Since then we have improved the precision of our measurements and more than doubled the number of samples we can process at sea. We have been an active part of the DOE science team and have contributed to several related DOE projects like the development of the DOE Methods Handbook [DOE, 1994] and instrument intercomparison exercises and training workshops. The underway $\mathrm{pCO}_{2}$ instrument developed in our lab was selected by the science team to make measurements on every leg of the Indian Ocean survey. It ran nearly continuously during the 14 months of back-to-back cruises and generated approximately 200,000 surface seawater and 50,000 marine air $\mathrm{pCO}_{2}$ measurements. Princeton's portion of the field program was completed in September of 1997 with the completion of two meridional sections in the western North Atlantic. All data have been reported to the Carbon Dioxide Information Analysis Center (CDIAC) and are either published or in preparation.

The Princeton $\mathrm{CO}_{2}$ measurement program has been a perfect complement to the modeling and radiocarbon measurement programs already established at Princeton. Recent results from an analysis of the anthropogenic $\mathrm{CO}_{2}$ distributions in the Indian Ocean, based on the survey data, have clearly convinced us of the importance and value of ocean measurements in constraining the oceanic sink of anthropogenic carbon dioxide. They also have reinforced our concern over their spatial and temporal coverage, their quality, and the proper way to interpret those measurements. Our involvement in the measurement program has helped us to address some of the important issues raised by our models. The improvement in the precision and accuracy of the measurements along with the significant increase in spatial coverage in the Pacific, Indian and Atlantic Oceans make the carbon data set collected by the DOE survey team a valuable tool for verifying and improving upon our model results.

\section{Analytical Program}

The Princeton Ocean Tracers Laboratory (OTL) joined the $\mathrm{DOE} \mathrm{CO} 2$ Science Team in January, 1993 to stimulate closer ties between the measurement program and our on-going modeling work supported by DOE. After helping to develop the $\mathrm{CO}_{2}$ sampling program at the JGOFS Hawaii Ocean Time-series station and completing his $\mathrm{Ph}$.D., Chris Sabine was hired as a post-doc to establish a $\mathrm{CO}_{2}$ measurement laboratory as part of this program. Prior to the official start date for this grant, Sabine and Key were able to design and build an automated underway $\mathrm{pCO}_{2}$ system using matching funds from Princeton University. This completely automated system determines the partial pressure of carbon dioxide $\left(\mathrm{pCO}_{2}\right)$ in both the atmospheric and oceanic mixed layers. A 


\section{DISCLAIMER}

This report was prepared as an account of work sponsored by an agency of the United States Government. Neither the United States Government nor any agency thereof, nor any of their employees, make any warranty, express or implied, or assumes any legal liability or responsibility for the accuracy, completeness, or usefuiness of any information, apparatus, product, or process disclosed, or represents that its use would not infringe privately owned rights. Reference herein to any specific commercial product, process, or service by trade name, trademark, manufacturer, or otherwise does not necessarily constitute or imply its endorsement, recommendation, or favoring by the United States Government or any agency thereof. The views and opinions of authors expressed herein do not necessarily state or reflect those of the United States Government or any agency thereof. 


\section{DISCLAIMER}

Portions of this document may be illegible in electronic image products. Images are produced from the best available original document. 
computer records the instrument signals and also controls a selector valve which alternately samples four gas standards, air from the bow/stern of the ship (depending on apparent wind direction), and air from the seawater equilibrator (Figure 1). The equilibrator is a modified disk-stripper de-

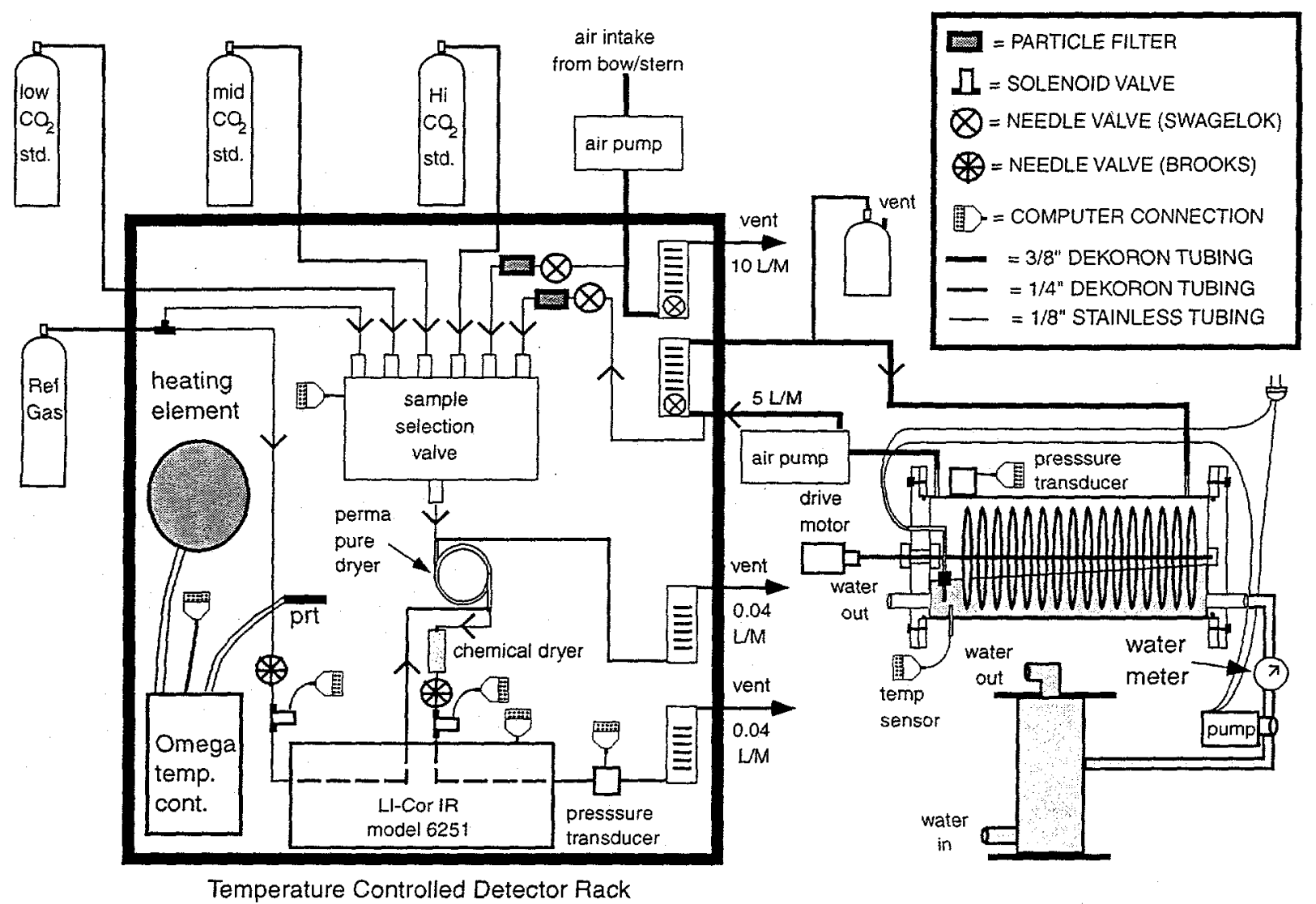

Figure 1: Schematic diagram of Princeton $\mathrm{pCO}_{2}$ system showing all major components.

sign that was found to be very efficient at removing radon from seawater. Laboratory and field tests of the modified design have proven it to be a very efficient equilibrator [Sabine et al., 1994]. Water and air are equilibrated with a half time of approximately 1 minute under standard operating conditions. The change-over from one $\mathrm{pCO}_{2}$ concentration to another in a system like this is like an exponential dilution curve. A half time of 1 minute means that the difference between the initial $\mathrm{pCO}_{2}$ concentration and the final concentration is cut in half every minute. This rate appears to be as good or better than other systems currently being used. As the half time decreases, the ability of the system to measure small scale ocean variability increases.

In October 1992, Chris Sabine participated in the WOCE/WHP cruise P16A/P17A (Juno 1) aboard the RN Knorr in the South Pacific. Sabine assisted the LDEO group in their analysis of $\mathrm{TCO}_{2}$ and discrete $\mathrm{pCO}_{2}$ 's. We planned to test the new $\mathrm{pCO}_{2}$ system on this cruise, however, this was prevented by shipping schedules. The system was available for the next leg, however, so Bob Key remained on board and ran the system on P17E/P19A (Juno 2). The system proved to be very reliable and results compared well with Ray Weiss' underway system that was also aboard for this leg. Underway data have been finalized as reported by Sabine and Key [1998a,b] and reported to CDIAC.

After returning from these cruises, a closed-cell alkalinity system was constructed. Our al- 
kalinity cell is modeled after the 100cc acrylic cells used by C. Goyet's group (WHOI), however, we have improved on the plumbing for sample transfer and rinsing of the cell. Our system is packaged in a box similar to the SOMMA with quadrants containing a water bath, a 665 Dosimat digital burette, a variable speed peristaltic pump and electronically actuated three-way valves, and a magnetic stirplate and cell assembly. The rinsing, filling and draining of the cell is accomplished with a switch box for the valves and pump. Once the cell is full, the entire titration is computer controlled. The computer checks the electrode stability, takes readings, and monitors acid addition. Both equal volume and equal potential titrations are possible with this system. After a run, TA and $\mathrm{TCO}_{2}$ are calculated using the non-linear algorithm described in the $\mathrm{DOE} \mathrm{CO}_{2}$ handbook [DOE, 1994]. After acquiring a SOMMA system for $\mathrm{TCO}_{2}$ analyses, the Princeton $\mathrm{CO}_{2}$ group had full responsibility for WOCE WHP leg P10. With one alkalinity and one SOMMA system, we were able to process nearly $1300 \mathrm{TA}$ and $\mathrm{TCO}_{2}$ samples on the 36 day cruise. Preliminary results were described by Sabine and Key [1993]. The underway $\mathrm{pCO}_{2}$ system was also run throughout the cruise. The data were finalized and submitted to CDIAC in September, 1996. The final numeric data package (NDP) is pending release of the final hydrographic data.

The Princeton underway $\mathrm{pCO}_{2}$ system was installed aboard the $R /$ Knorr in November 1994 prior to the first leg of the Indian Ocean survey. By the end of the survey on January 22 , 1996, nearly 200,000 surface seawater and 50,000 marine air $\mathrm{pCO}_{2}$ measurements were recorded. After the first leg, at least one person from the OTL lab was aboard to watch the system and ensure that the highest quality data were collected. Seawater values ranged from 310 ppm to greater than $610 \mathrm{ppm}$. The lowest values ( $\sim 50 \mathrm{ppm}$ below atmospheric) were measured in the southwestern Indian Ocean, south of Madagascar. The highest values (more than $250 \mathrm{ppm}$ higher than atmospheric) were found in the Arabian Sea and were associated with the southwest monsoon upwelling. In addition to the final post-cruise $\mathrm{CO}_{2}$ calibration exercises, a careful calibration of the ship's underway temperature and salinity data was necessary. The final calibrated and quality controlled underway hydrographic data were reported to the WOCE office and the WOCE Data Assembly Center for Surface Meterology at Florida State University. Final underway hydrographic and $\mathrm{CO}_{2}$ data were reported to CDIAC and published in November 1997 as NDP-064 [Sabine and Key, 1997].

The OTL carbon group also had full responsibility for the discrete $\mathrm{TCO}_{2}$ and TA measurements on legs I9N (from Fremantle, Australia to Colombo, Sri Lanka) and I10 (from Dampier, Australia to Singapore) in the Indian Ocean. The results of these cruises were summarized by Sabine $[1995 ; 1996 \mathrm{a}]$. By taking four people to sea and working two sets of instruments, we were able to analyze over 3500 samples ( $>55 \%$ of total number of hydrographic samples) for both $\mathrm{TCO}_{2}$ and TA on these two cruises. This sampling frequency represents a better than $50 \%$ increase over the average sampling frequency of most groups in the Pacific. This increased frequency will help reduce the errors in future inventory and carbon transport estimates in these regions.

The global survey was completed in mid 1997 with sampling of the North Atlantic. The OTL had responsibility for discrete TA and underway $\mathrm{pCO}_{2}$ measurements on legs $\mathrm{A} 20$ and $\mathrm{A} 22$ in the western North Atlantic. Over 1500 and 1250 TA samples were analyzed on the $52^{\circ} \mathrm{W}$ (A20) and the $66^{\circ} \mathrm{W}$ (A22) legs, respectively. These data have been finalized and reported to CDIAC.

\section{Synthesis Efforts}

Our ties with other DOE and WOCE programs have helped to integrate the DOE $\mathrm{CO}_{2}$ measurement program with other related research in this area. The Princeton OTL radiocarbon 
group has also had primary responsibility for the collection of large volume and $\mathrm{AMS}{ }^{14} \mathrm{C}$ samples in the Pacific and Indian Ocean WOCE/WHP survey cruises. Our links, through Bob Key, between the $\mathrm{CO}_{2}$ and ${ }^{14} \mathrm{C}$ programs have helped to coordinate sample collections of these related measurements to provide the most useful data coverage. Both the $\mathrm{CO}_{2}$ and ${ }^{14} \mathrm{C}$ programs can be tied back to our modeling program. This program, headed by Jorge Sarmiento, has helped to identify important areas that need to be studied as well as an evaluation of the precision, accuracy, and sample coverage necessary to address the problems of the carbon cycle and global change. Where measurement programs such as this can get bogged down in details and specifics of individual legs, our direct ties with the modelers help us to keep the "big picture" in focus. The Princeton group has already started the synthesis process by examining the Indian Ocean (where the $\mathrm{CO}_{2}$ data are the best). Preliminary results have been very rewarding with a confirmation that the quantity and quality of the global survey data are sufficient to isolate the anthropogenic $\mathrm{CO}_{2}$ signal [Sabine et al., 1997a; 1997b; 1998]. To date, the interaction between the measurement and modeling programs has been limited, but initial investigations suggest that the survey data can provide very strong constraints for evaluating the models [Orr et al., 1998; Sabine and Key, 1998c]. As the survey data become finalized these two groups will interact to a much greater extent.

\section{References $^{1}$}

DOE, Handbook of Methods for the Analysis of the Various Parameters of the Carbon Dioxide System in Sea Water, Version 2, A.G. Dickson and C. Goyet, eds., ORNL/CDIAC-74, 1994.

Johnson, K.M., A.G. Dickson, G. Eischeid, C. Goyet, P. Guenther, F.J. Millero, D. Purkerson, C.L. Sabine, R.G. Schottle, D.W.R. Wallace, R.J. Wilke, and C.D. Winn, Coulometric total carbon dioxide analysis for marine studies: Assessment of the quality of total inorganic carbon measurements made during the US Indian Ocean $\mathrm{CO}_{2}$ Survey 1994-1996, Marine Chemistry, in press, 1998.

Millero, F.J., A.G. Dickson, G. Eischeid, C. Goyet, P. Guenther, K.M. Johnson, K. Lee, D. Purkerson, C.L. Sabine, R.G. Schottle, D.W.R. Wallace, R.J. Wilke, and C.D. Winn, Total alkalinity measurements in the Indian Ocean during the WOCE Hydrographic Program $\mathrm{CO}_{2}$ survey cruises 1994-1996, Marine Chemistry, in press, 1998.

Orr, J.C., J.L. Sarmiento, P. Monfray, E. Maier-Reimer, J. Palmer, N.K. Taylor, N. Dufourg, C. LeQuere, N. Gruber, C. Sabine and R.M. Key, Anthropogenic $\mathrm{CO}_{2}$ in the ocean: predictions from four 3-D global ocean carbon-cycle models, Global Biogeochemical Cycles, in prep., 1998.

Sabine, C.L., Indian Ocean $\mathrm{CO}_{2}$ survey moves north, U.S. JGOFS News, 6, 3, 1995.

Sabine, C.L., Survey of throughflow waters in eastern Indian Ocean hampered by Indonesian security concerns, U.S. JGOFS News, 7, 3, 1996a.

Sabine, C.L., The global survey of $\mathrm{CO}_{2}$ in the oceans, Li-Cor Newsline, $1996 \mathrm{~b}$.

Sabine, C.L. and R.M. Key; U.S. JGOFS $\mathrm{CO}_{2}$ survey moves into the far western Pacific, U.S. JGOFS News, 5, 2, 1993.

Sabine, C.L. and R.M. Key, A new instrument design for continuous determination of oceanic pCO $\mathrm{C}_{2}$, Tech. Rep. \#96-12, Ocean Tracer Laboratory, Dept. of Geosciences, Princeton Univ., Princeton, NJ, 20 pp., 1996. 
Sabine, C.L. and R.M. Key, Surface Water and Atmospheric Underway Carbon Data Obtained During the World Ocean Circulation Experiment Indian Ocean Survey Cruises $(R V$ Knorr, December 1994-January 1996), ORNL/CDIAC-103, NDP-064, Carbon Dioxide Information Analysis Center, Oak Ridge National Laboratory, Oak Ridge TN, 89 pp., 1997.

Sabine, C.L. and R. M. Key, Controls on $\mathrm{fCO}_{2}$ in the South Pacific, Marine Chemistry, 60, 95$110,1998 \mathrm{a}$.

Sabine, C.L. and R.M. Key, Final Report for Underway Surface $\mathrm{CO}_{2}$ Measurements on WOCE Leg P17E/P19S, Tech. Rep. \#98-3, Ocean Tracer Laboratory, Dept. of Geosciences, Princeton Univ., Princeton, NJ, 13 pp., 1998 b.

Sabine, C.L. and R.M. Key, Looking for fossil fuel $\mathrm{CO}_{2}$ in the oceans, 1998 U.S. WOCE Report, in press, $1998 \mathrm{c}$.

Sabine, C.L., R.M. Key and G.J. McDonald, Princeton $\mathrm{pCO}_{2}$ System Operation Manual, Tech. Rep. \#94-1, Ocean Tracers Laboratory, Dept. Geol. Geophys. Sci., Princeton Univ., Princeton, NJ, Nov. 1994.

Sabine, C.L., R.M. Key, C. Goyet, K.M. Johnson, F.J. Millero, A. Poisson, J.L. Sarmiento, D.W.R. Wallace and C.D. Winn, Anthropogenic $\mathrm{CO}_{2}$ inventory of the Indian Ocean, Global Biogeochemical Cycles, submitted, 1998.

Sabine, C.L., D.W.R. Wallace and F.J. Millero, Survey of $\mathrm{CO}_{2}$ in the oceans reveals clues about global carbon cycle, EOS, 78, 5,49-55, $1997 \mathrm{a}$.

Sabine, C.L., D.W.R. Wallace and F.J. Millero, Keeping our cool: Does the ocean dampen the greenhouse effect? Earth in Space, 10-14, 9 (8), 1997b. 